\title{
Understanding And Confronting Alcohol-Induced Risky Behavior Among College Students
}

Lucien J. Dornier, Southeastern Louisiana University, USA

Katharine J. Fauquier, Southeastern Louisiana University, USA

April R. Field, Southeastern Louisiana University, USA

Michael C. Budden, Southeastern Louisiana University, USA

\begin{abstract}
Confronting alcohol abuse is a challenge for most higher education institutions. Each year, students are admitted to hospitals for issues arising from the misuse of alcohol. The deaths of some engaged in alcohol related activities is especially worrisome. Factors such as age and financial standing could impact the likelihood of abuse. So-called drinking "games" have potentially altered student perceptions of alcohol consumption and may lead to reckless behavior. This study looks at perceptions of alcohol use among college students and investigates the level of support a late night shuttle system might garner if offered to students on a college campus.
\end{abstract}

Keywords: Reckless Behavior, Alcohol Education, Drinking and Driving, Sober Shuttle, Students

\section{BACKGROUND}

n the early morning hours of March 6, 2009 tragedy struck the campus. Two Southeastern students and one alumnus walking home from an off-campus bar were killed and two other students injured after being struck by a hit and run driver. A 21-year-old who was believed to be intoxicated was apprehended shortly after the incident. The tragedy sent shock waves and spread grief throughout campus. Even though the University has a strict alcohol use and education policy, and the incident happened off campus, questions arose as to what more could or should be done to protect students (Sanders, 2009).

\section{University Alcohol Education Grant}

The University received a $\$ 68,000$ grant from the Louisiana Highway Safety Commission in September 2009. The grant was given to improve on-campus alcohol education and awareness efforts. The yearlong grant will focus on two major areas-student mentoring and peer counseling programs and campus alcohol education programs. The Southeastern Louisiana University Counseling Center will be working with on-campus organizations to coordinate an appropriate plan of action. This grant was sought following the incident (Abadie, 2009).

\section{Spending on Alcohol}

The amount of money a student spends on relates to their resources. Simply, the more money a student has to spend on alcohol the more they can spend. A recent study indicated students in the higher income brackets are more likely to drink than those in the lower income brackets (Cook 2007). Furthermore, Cook (2007) found a 10\% increase in average income led to a $3.4 \%$ increase in average alcohol sales. The more discretionary funds a student has the higher the likelihood of the students to drink (Cook, 2007).

Research indicates the amount spent on alcoholic beverages by students varies but some have been found to spend over $\$ 500$ in a month. One study found 33\% of women and 32\% of men spent between $\$ 100$ and $\$ 199$ per month on alcohol. (Martin, et al. 2009) Another study found students have approximately $\$ 172$ in discretionary 
spending money per month. This is significant considering the amount of money spent on alcohol is in the same range. (Gladieux \& Lee 2001).

Typical college students have limited discretionary funds. Researchers have found that the price of alcohol will affect younger drinkers because they are more price sensitive than an adult with a higher income. Therefore, some believe raising the price of alcohol will reduce the amount of drinking thereby reducing reckless behavior associated with heavy drinkers (Hingson et al 2005). Bar and nightclub owners in college towns are especially aware of the price sensitivity of college students. Drink specials and promotions to encourage the consumption of alcohol among college students is a very common practice. Local policy makers can affect the price of alcohol by prohibiting bars, restaurants, and nightclubs from offering drink specials that are highly discounted from regular price (Chaloupka, Grossman \& Saffer 2002).

\section{Binge Drinking}

Binge drinking can be a major problem. Forty percent of U.S. undergraduates engage in heavy drinking having five drinks in a row in a two-week period (Johnston et al 2005). The affects of binge drinking are tremendously adverse. Those who binge drink are more likely to engage in reckless behavior such as unplanned sexual activity, driving intoxicated, damaging property, injury, and death. It is estimated that 1,700 college students ages 18-24 die annually from alcohol-related unintentional injuries. Nearly 80 percent of those deaths are associated with driving after drinking. Additionally, in 200110 percent of college students reported being injured and 8 percent reported having unprotected sex because of their drinking (Hingson et al 2005).

Not only does drinking affect the safety of oneself and others but academics are also affected by drinking habits. A study reported that students with an A average consume an average of 3.4 drinks per week. While a D-F student consumes an average of 9.8 drinks in a week (Presley, Meilman \& Cashin 1996).

In the college setting, binge drinking is most common to male, Caucasian, members of fraternities or sororities, and varsity athletes. This is due to the environment in which they find themselves (O'Malley \& Johnston 2002). Students who live in Greek houses tend drink the most, followed by students who live on campus. This is due to those settings becoming a place to meet and socialize (Wechsler et al 2000). Starting college brings a great deal of responsibility and stress which allows peer pressure to play a role in the consumption of alcohol due to the desire to fit in and be socially successful (Chapman \& Zaballero 2006).

Colleges have not been idle. They have taken and continue to take steps to combat drinking behaviors that lead to risky behaviors. Some colleges provide alcohol free options such as creating alcohol-free events for first time students, expanding hours of recreation centers, and supporting clubs that are substance free. A few other steps include restricting the alcohol availability, restricting marketing and promotion of alcohol, and strengthen drug and alcohol policies (Zimmerman \& DeJong 2003).

\section{Pre-Partying}

A recent study investigated pre-partying or pre-gaming - consuming alcohol before attending an event or activity at which more alcohol may be consumed. During pre-partying students drink multiple drinks in a short period of time to become intoxicated. This dangerous behavior can lead to alcohol induced illnesses such as nausea, blackouts, and alcohol poisoning. Pre-partying can lead to larger quantities of alcohol being consumed (Pedersen \& LaBrie 2007).

A study of pre-party drinking behaviors found when pre-partying, men engage in heavy drinking behavior $84 \%$ of the time, compared to $63 \%$ of the time on a normal drinking day. Women engaged in heavy drinking $83 \%$ of the time compared to $49 \%$ on normal drinking days. The results show that pre-partying clearly promotes heavy drinking behavior. The reason for pre-partying was determined to be social motives for both women and men (Pedersen \& LaBrie 2007). 


\section{Lowering the Legal Drinking Age}

Perhaps one of the more controversial recommendations to lower dangerous drinking is to lower the legal drinking age to 18 years of age. The issue has long been popular with Libertarian groups and conservative economic foundations. Perhaps surprisingly some university administrators have been pushing to lower the drinking age. College administrators may seem like an unlikely choice to champion lowering the drinking age, but these college leaders have personal experience with the issues of college drinking and believe lowering the age will result in less abuse of alcohol. This position evokes strong emotions from the opposition.. A former president of Middlebury College in Vermont is a leader in the movement to lower the legal drinking age (Johnson 2007).

While there is no "federal legal drinking age" in existence, all U.S. states currently have the legal drinking age set at 21 years old. In the mid-1980's, states were pressured by Congress to raise their drinking age to 21. States that did not comply, most notably Louisiana, had millions in federal funding pulled and faced legal headaches. "Raising the drinking age to 21 was passed with the very best of intentions, but it's had the very worst of outcomes," said David J. Hanson, an alcohol policy expert at the State University of New York-Potsdam. "Just like during national Prohibition, the law has pushed and forced underage drinking and youthful drinking underground, where we have no control over it (Johnson 2007).

A 2005 National Survey on Drug Use and Health found that $85 \%$ of 20 -year-old Americans claimed to have consumed alcohol. Disturbingly, $40 \%$ of those who have consumed alcohol reported that they had engaged in binge drinking, or consumed five of more drinks at one time (Johnson 2007).

Some believe that by making it illegal for young adults to drink society is effectively driving their behaviors underground. These behaviors, since they have no legal basis, have no limits. Such behaviors can and too often do lead to risky behaviors that place not only the drinker at risk, but others as well.

\section{Sober Shuttle Programs}

One potential solution to drinking and driving are school and student sponsored sober shuttle systems. These systems involve buses that drive students to and from bars to on-campus housing and area apartment complexes and neighborhoods. These programs can be financed in a variety of ways. Financing can come from student fees, private donations, government grants and advertising revenue. In addition, if allowed and permitted, guest riders accompanying students may be required to pay a usage fee. These programs, while not eliminating drinking and driving, provide students with a safe avenue to consume alcohol.

The University of Oregon currently has a student-run sober shuttle program. The program is completely funded and run by volunteer students. They have adopted a "no questions asked" policy to alleviate student concerns about legal repercussions for underage or excessive drinking. The University of Oregon supports the project, but does not contribute financial or labor resources. As a model, this program may not be ideal for all. Students elsewhere may not be willing to voluntarily fund such a program. Student financial support, while helpful, should not be expected (Betz, 2006).

The city of Baltimore runs a sober shuttle system that serves students from five area universities. The service was estimated to have carried 65,000 riders last year. Students are required to display student ID's to board the bus. The city and Baltimore-area institutions fund the bus. The program was initiated to make the Baltimorearea more appealing to prospective students and recognizes that students need to get from campus to campus and to social destinations (Willis, 2005).

\section{Model Programs - No Need to Reinvent the Wheel}

Basic awareness and education programs, although a major part of any prevention effort are often less than successful. These programs include orientation sessions for new students, alcohol awareness weeks, other special events, and curriculum including alcohol-related facts and issues (DeJong et al 2009). To improve programs, colleges and universities must take responsibility for their students and make an effort to educate them in hands-on 
ways. The U.S. Department of Education has compiled award-winning model programs from over thirty-four colleges and universities to address alcohol and other drug problems (Alcohol and Other Drug Prevention on College Campuses, 2008). Reviewing these programs may be a good starting point before contemplating an alcohol awareness program.

Pittsburg State University in Pittsburg, Kansas offers a program called "Safe Ride." The Student Government Association started the program where students may call when they need a ride home from on or off campus. Student-drivers are on-call to provide a safe ride home. The service runs Wednesdays through Sundays from 11:00 pm-2:30 am. Local restaurants donate food to the drivers who volunteer. Student fees pay for this service (Bacchus 2004).

The University of Kentucky sponsors a "Reality Check" program that is put on several times each year. Students are lured with free t-shirts, food, and an entertaining way to educate. During this event, students put on intoxication-simulated goggles and perform tasks such as hopscotch, shooting water guns, and dribbling a basketball. The activities take place in the middle of campus and the counseling center has a table set up to give out resources, brochures, and alcohol poisoning cards (Bacchus, 2004).

College students as a group engage in heavy drinking episodes at a higher rate than non-college students (Bachman, O'Malley \& Johnston, 1984; O'Malley \& Johnston 2002). McGuire and Nunn (2006) believe that universities have both a right and a duty to provide a safe environment. Thus the need to be forthcoming and to find viable solutions is paramount.

\section{Marketing}

A recent study found a decrease in heavy drinking from students after promoting a media campaign by correcting misconceptions about student drinking habits (Perkins, 2003). Many students attend college with a common perceived image that all college students drink heavily. Another study demonstrated such misperceptions at more than 100 institutions (Perkins et al 1999). By studying a university's culture of drinking, Universities can better understand the problem and communicate the solution in an effective manner. As Budden et al (2007) found, the need to reach students through non-traditional media is increasingly important. While internet usage is increasing rapidly, the internet and mobile media are being heavily utilized by college students. With this in mind, it is important to utilize venues like Facebook, MySpace, and YouTube to both reach and appeal to college students.

\section{RESEARCH METHODOLOGY}

A convenience sample of students $(n=203)$ was used to test several hypotheses. Questionnaires were distributed in fall 2009 on campus. The respondents were primarily 21 years old and older (57\%) and roughly $43 \%$ were underage (18-20 years old). Males made up 32\% of the respondents while females made up $68 \%$. This is not too unlike the gender breakdown for the University, where 37\% are male and $63 \%$ female (SoutheasternProfile, 2008).

\section{FINDINGS}

\section{Objective 1}

The first objective was to determine perceptions as to how often students go to bars/clubs to consume alcohol. The results indicate that $37.9 \%$ of the students surveyed believe students go to bars/clubs two or more times a week. Another $46.8 \%$ of the students surveyed believe that students go to the bars/clubs at least once a week. The remaining $15.3 \%$ of the students surveyed believe that students go to a bar/club once a month or less. Though Southeastern Louisiana University is a commuter school, bars and clubs are perceived to be hot attractions for the majority of the student body. 


\section{Objective 2}

The second objective was to determine how often students believe students consume alcohol at home. The findings reveal $39.4 \%$ of the students surveyed believe that students consume alcohol at home two or more times per week. Nearly the same amount, $34.5 \%$, believes that students consume alcohol at home once per week. Additionally, $17.2 \%$ believe that students drink at home once a month. This leaves $8.9 \%$ to believe that students drink at home less than four times in a year.

\section{Objective 3}

The third objective was to investigate the prevalence of drinking games during the consumption of alcohol. The results indicate $18.2 \%$ of students surveyed believe that of the students who consume alcohol over $75 \%$ play drinking games. Another $36 \%$ of students surveyed believe that between $51 \%$ and $75 \%$ of students who consume alcohol play drinking games. Additionally, $30 \%$ of the people surveyed believe that between $25 \%$ and $50 \%$ of students who consume alcohol play drinking games.

\section{Objective 4}

The findings indicate $19.3 \%$ of students surveyed believe students who consume alcohol play drinking games two or more times a week. Also, $38.6 \%$ of the students surveyed believe that students who consume alcohol play drinking games at least once a week. Nearly one-third, $32.2 \%$ believe students who drink play drinking games at least once a month. Thus, $90 \%$ of respondents believe that students who drink are likely to participate in drinking games at least once per month. Since more than $65 \%$ of respondents felt that students who participate in drinking games consume more alcohol as a result of participation, this finding is particularly troublesome.

\section{Objective 5}

The fifth objective investigated perceptions as to the likelihood of game participation leading to risky behaviors. Examples of reckless behavior were defined as drinking and driving, fighting and unplanned sexual activity. Approximately $43 \%$ of respondents felt that students who play drinking games are more likely to engage in reckless behavior. Another one-third of respondents indicated that students who engage in drinking games are just as likely to participate in reckless behavior as others. Just $15.8 \%$ of respondents felt students who play drinking games are not likely to drink and drive, fight or have unplanned sexual activity

\section{Objective 6}

The sixth objective was to determine perceptions as to how much money was being spent on alcohol by students on an average night out. The perception by $43.3 \%$ of respondents is that students spend between $\$ 20-39$ on alcohol during an average night. The next two levels of spending were just below and above $\$ 20-39,28.6 \%$ of the students' surveyed chose $\$ 10-19$ and $14.3 \%$ chose $\$ 40-59$ spent on an average night. A small percentage of students chose $\$ 5-9$ (4.9\%), $\$ 0-4(4.4 \%)$, and $\$ 60$-more (4.4\%). This objective was included to provide insight into the amount of alcohol students consume. The most popular response, $\$ 20-39$, would likely buy four or more drinks in area bars.

\section{Objective 7}

The seventh objective was to determine perceptions as to how often students are believed to drive after consuming alcohol. Findings are displayed in Chart 1 . The majority of respondents (57\%) believe students drive quite often after consuming alcohol. Just 3\% of respondents felt that students never drive after consuming alcohol. This finding points out the need to educate and provide solutions for students who will possibly engage in risky behavior. 
Chart 1: How often do you believe university students drink and drive?

\begin{tabular}{|l|l|l|l|l|l|l|}
\hline $\begin{array}{c}\text { Would you support a sober } \\
\text { shuttle service? }\end{array}$ & \multicolumn{1}{|c|}{ Never } & \multicolumn{1}{|c|}{ Once } & \multicolumn{1}{|c|}{ Seldom } & Quite Often & Don't Know & \multicolumn{1}{|c|}{ Total } \\
\hline Yes & $4(2 \%)$ & $2(1 \%)$ & $47(24 \%)$ & $93(49 \%)$ & $8(4 \%)$ & $154(79 \%)$ \\
\hline No & & $1(0.5 \%)$ & $8(4 \%)$ & $9(5 \%)$ & $2(1 \%)$ & $20(10 \%)$ \\
\hline Don't Know & $2(1 \%)$ & $1(0.5 \%)$ & $4(2 \%)$ & $11(6 \%)$ & $4(2 \%)$ & $22(11 \%)$ \\
\hline Total & $6(3 \%)$ & $4(2 \%)$ & $59(30 \%)$ & $113(57 \%)$ & $14(7 \%)$ & $196(100 \%)$ \\
\hline
\end{tabular}

Note: percentages are rounded

\section{Objective 8}

The eighth objective was to determine if students were aware of on-campus counseling and education, and if students used these resources. The majority of respondents (60.4\%) indicated they had never attended an oncampus alcohol education program or had visited the counseling center for alcohol-related services. Approximately one-fourth of respondents have utilized campus resources and surprisingly, $12.4 \%$ reported they were unaware the University had alcohol related events or counseling. These results show that the school has an opportunity to improve programming and counseling. Holding student-friendly activities that are fun and educational, and promoted effectively is needed.

\section{Objective 9}

The ninth objective was to determine if students would support an on-campus sober shuttle service for a fee of $\$ 10$ per semester. More than three-quarters of respondents $(78.6 \%)$ indicated they would support a campussponsored shuttle system for a fee of $\$ 10$ per semester. Only $10.2 \%$ of respondents stated that they would not support a campus shuttle system while $11.2 \%$ of students surveyed stated that they were unsure whether they would support a shuttle system. An interesting finding is that the majority of students who believe college students drink and drive often were likely to support the shuttle idea.

Estimated costs of a sober shuttle program (not counting bus acquisition) for the University's market area are displayed in Chart 2.

Chart 2: Estimated Sober Shuttle Budget

\begin{tabular}{|c|c|c|}
\hline Expense & Cost & Nightly Total \\
\hline Security Wages & $\$ 25 /$ Hour & $\$ 125$ (\$25*5 hours) \\
\hline Driver Wages & $\$ 16 /$ Hour & $\$ 80(\$ 16 * 5$ hours $)$ \\
\hline Mileage \& Maintenance & $\$ 0.55 /$ Mile or $\$ 8.25 /$ Trip & $\$ 247.50(\$ 8.25 * 30$ trips $)$ \\
\hline Nightly Total & & \$452.50/ Night \\
\hline Semester Total & 4 Nights $* 16$ Weeks & $\$ 28,960 /$ Semester \\
\hline
\end{tabular}

The estimated budget indicates that a semester cost of $\$ 28,960$ would be required to run a shuttle program. The budget covered a 16-week semester not including holiday weeks, an estimated round trip mileage of 15 miles and five hours operational time per evening. This operating budget does not include non-routine maintenance or vehicle replacement. As will be seen, a proposed fee of $\$ 10$ per student, per semester, will more than cover the costs of acquiring and operating such a shuttle service.

\section{Objective 10}

The tenth objective was to determine if students believe the legal drinking age should be lowered to 18 . Almost one-half (48\%) of respondents believed the legal drinking age should be lowered to 18 years of age. At the same time, $(39 \%)$ were opposed to lowering the legal drinking age to 18 despite the fact that two-thirds believed underage drinkers were more likely to binge drink. Perhaps like some others, they perceive the difficulties involved in getting alcohol by 18-20 years old students may actually lead to risky behaviors. 


\section{Objective 11}

The eleventh objective was to determine if students believed the hit and run incident involving the deaths of three in spring 2009 had an effect on student alcohol consumption. The accident had a dramatic impact on campus, but the incident's affect on the drinking habits of students' remains unclear. Results from the survey are displayed in Chart 3. Just $8 \%$ of students surveyed believe that alcohol consumption increased after the event. Approximately one-third (31\%) believed that alcohol consumption decreased after the incident. A little more than one-half (51.5\%) of respondents believed the incident did not have an effect on student alcohol consumption.

Chart 3: Do you believe the recent hit \& run incident had an impact on student drinking?

\begin{tabular}{|l|c|c|c|c|c|}
\hline $\begin{array}{c}\text { Do you believe that a } \\
\text { sober shuttle will reduce } \\
\text { drinking and driving? }\end{array}$ & $\begin{array}{c}\text { Yes, } \\
\text { consumption } \\
\text { increased }\end{array}$ & $\begin{array}{c}\text { Yes, } \\
\text { consumption } \\
\text { decreased }\end{array}$ & No & $\begin{array}{c}\text { I was not } \\
\text { aware of the } \\
\text { incident }\end{array}$ & Total \\
\hline Yes & $11(5 \%)$ & $52(26 \%)$ & $74(37 \%)$ & $9(4.5 \%)$ & $146(73 \%)$ \\
\hline No & $2(1 \%)$ & $6(3 \%)$ & $17(8.5 \%)$ & $2(1 \%)$ & $27(13.5 \%)$ \\
\hline Don't Know & $3(1.5 \%)$ & $5(2.5 \%)$ & $13(6.5 \%)$ & $7(3.5 \%)$ & $28(14 \%)$ \\
\hline Total & $16(8 \%)$ & $63(31 \%)$ & $104(52 \%)$ & $18(9 \%)$ & $201(100 \%)$ \\
\hline
\end{tabular}

Note: percentages are rounded

\section{Objective 12}

The survey included a question as to whether students would support a self-assessed fee to support a sober shuttle service in the area. Some $80 \%$ of respondents indicated they would support a $\$ 10$ per semester fee to provide a shuttle to area bars, in order to deter drinking and driving. The establishment and support of such a shuttle service would indicate that students are responsible and willing to work to reduce risky behaviors.

\section{RECOMMENDATIONS}

The first recommendation is for the university to conduct more extensive research on the issue of alcohol usage. The current survey studied opinions regarding student alcohol usage rather than actual personal drinking habits. Actual drinking behaviors as reported by students need to be assessed. Effective plans to curtail abuses could be developed based on such information.

The second recommendation is to conduct more frequent alcohol education programs on campus. Current programs, such as 'Mocktails' have received positive comments from attendees, but still not all are impacted and others need to be educated to further awareness. Activities using so-called beer goggles to simulate intoxication's effects on movement and coordination could augment Mocktails. Additional education efforts need to be both entertaining and educational to garner wider participation by students.

Third, a mandatory alcohol education program for students should be considered. Such a program could be included in the university's freshman experience class. Alternatively, an online module could be developed that would be a stand alone requirement for registration approval, similar to the "syllabus validation" requirement implemented last year. Universal alcohol abuse education can augment the other programs on campus.

The fourth recommendation is for the University to sponsor a sober shuttle service. Research, both primary and secondary has shown that education and awareness do not necessarily prevent dangerous behavior. While counseling and information are certainly necessary, they alone are not enough to protect students. Since some students are going to drink, universities can reduce accidents; injuries and deaths by providing students with safe transportation. In addition to reducing instances of drinking and driving, a shuttle bus can reduce other possible dangerous situations for students. Limited parking is an issue affecting many downtown areas, where bars and clubs are often located. A student walking from a bar to their car alone at night presents opportunities for criminals and places students at risk. 
A shuttle service is a visible and bold statement that the University wishes to improve student safety and encourage students to make better decisions while drinking. In order to be effective, a shuttle bus should allow students to board without the risk of getting into trouble for underage drinking. If students feel that the sober shuttle will open them up to receiving alcohol related citations, they will not use the service and may be prone to drink and drive.

There are several issues to consider when developing a shuttle program. A school must determine if they will allow non-students access to the service, and under what circumstances. Since some students may have friends/dates with whom they will drink, the question arises as to whom is allowed to ride and when. If a decision to allow non-student guests to ride, there may be implications for licensing the shuttle (for instance, as a taxi). Such licensing procedures and expectations will vary by locale and will undoubtedly play a role in planning such a program.

Another Shuttle issue that must be considered is when and how often to run the shuttle. The more often the shuttle is run, the higher the expenses for the program will be. It is recommended that the shuttle initially run on peak "party nights": Thursday, Friday and Saturday nights. The buses should run from 9:30 p.m. until 2:30a.m. Those are peak times for students to go to and from bars.

Security and safety are the most common problems that people are faced with when running a sober shuttle. It is strongly recommended that a police officer or security guard be on the buses to protect the safety of the driver and passengers. Security can be on hand to insure that passengers do not board the shuttle buses with alcohol. They can also be on hand to prevent passengers from acting or behaving inappropriately. Many universities allow Campus Police officers to be hired for security details after they complete their normal work hours, and any viable shuttle service will need to include police or security details.

There are several different options a university may use to pay for a shuttle system. It is recommended that the school use a variety of resources to fund such a program. The most costly expense is the initial cost of the buses. Buses that are utilized at our university for its parking shuttle service cost approximately $\$ 55,000$ each. Some universities with a parking shuttle service will already be in possession of buses that may be used for a sober shuttle service. Still, if a bus is already part of the university fleet, the initial dollar outlay will be minimal, but mileage and other expenses will need to be covered.

In the current survey, students overwhelmingly reported they would be willing to pay a self-assessed fee of $\$ 10$ per semester to provide a sober shuttle service. Nearly $80 \%$ of respondents said that they would support the program at that level. Southeastern's current enrollment of 15,224 students (Southeastern Profile, 2008) would produce $\$ 152,240$ each for fall and spring semesters. With a summer enrollment of 4,000 another $\$ 40,000$ would be collected for the service. Thus, in a given year approximately $\$ 345,000$ would be generated. Since the school's current parking shuttle buses could do double duty, at least in the short run, a $\$ 10$ fee would be more than enough to cover the cost of a sober shuttle service, including acquisition.

Other sources of revenue support for a shuttle service would be to seek federal or state grants for the program and to seek support from bar owners While government funding is never a guarantee, it is worth seeking. Funding can also come from bars and restaurants. Establishments could pay a fee to be a stop on the shuttle route. Local businesses could also pay to advertise on the buses. The University's parking shuttles boasts in-bus monitors which can display advertisements.

\section{AUTHOR INFORMATION}

Katharine Fauquier is a Masters of Business Administration student at Southeastern Louisiana University. Katharine currently works at a Public Relations firm in Metairie, Louisiana where she specializes in media strategy, marketing research, cause marketing and social media.

April R. Field is a Masters of Business Administration student at Southeastern Louisiana University. Her research interests include business education, organizational management, educational leadership, and ethics. 
Lucien Dornier is a Masters of Business Administration student at Southeastern Louisiana University. His interests include organizational communication, marketing and management.

Michael C. Budden is the Mayfield Professor of Marketing at Southeastern. His research interests include ethics, commercial law, business education, retail management and health care marketing.

\section{REFERENCES}

1. Abadie, R., (2009). Southeastern receives grant to combat alcohol abuse. Retrieved from http://www.selu.edu/news_media/news_releases/2009/sept/alcohol_grant.html

2. Alcohol and other drug prevention on college campuses (2008). U.S. Department of Education [pp. 01-41]. Retrieved from http://www.higheredcenter.org/files/product/model.pdf

3. BACCHUS. (2004). Model impaired driving prevention programs. Retrieved from http://www.friendsdrivesober.org/programming/model_programs.html

4. Bachman, J.G., O'Malley, P.M., \& Johnston, L.D. (1984). Drug use among young adults: The impacts of role status and social environment. Journal of Personality \& Social Psychology, 47, 629-645.

5. Betz, A. (2006). Designated Driver Shuttle. Retrieved from http://www.uoregon.edu/ asuodds/mission.html

6. Budden, C.B., Anthony, J.F. Budden, M.C., \& Jones, M.A. (2007). Managing the evolution of revolution: Marketing implications of internet media usage among college students. The College Teaching Methods \& Styles Journal, 3(3), 05-10.

7. Chaloupka, F.J., Grossman, M., \& Saffer, H. (2002). The effects of price on alcohol consumption and alcohol-related problems. Alcohol Res Health, 26: 22-34.

8. Chapman, R.J., \& Zaballero, A. (2006). When they drink: alcohol and the first-year experience as seen by students. In When they drink: practitioner views and lessons learned on preventing high-risk college drinking, Chapman RJ., ed. Glassboro, NJ.: Rowan University Press.

9. Cook, P. (2007). Paying the tab: the costs and benefits of alcohol control. Princeton, NJ: Princeton University.

10. DeJong, W., Larimer, M.E., Wood, M.D., \& Hartman, R. (2009). Niaaa's rapid response to college drinking problems initiative: Reinforcing the use of evidence-based approaches in college alcohol prevention. Journal of Studies on Alcohol and Drugs, 70, (Supplement 16), 05-11.

11. Gladieux, L.E., \& Lee, J.B. (2001). Credit card use by undergraduates: California and the nation. Rancho Cordova, CA: EdFund.

12. Hingson, R., Heeren, T., Winter, M., \& Wechsler, H. (2005). Magnitude of alcohol-related mortality and morbidity among U.S. college students ages 18-24: Changes from 1998 to 2001. Annual Review of Public Health 26: 259-279,

13. Johnson, A. (2007). Debate on lower drinking age bubbling up. Retrieved from http://www.msnbc.msn.com/id/20249460/ns/health-addictions//

14. Johnston, L.D., O’Malley, P.M., Bachman, J.G., \& Schulenberg, J.E. (2005). Monitoring the future: National survey results on drug use, 1975-2004. Volume II: College Students and Adults Ages 19-45. Washington, D.C.: National Institutes of Health.

15. Martin, B.A., McCoy, T.P., Champion, H., Parries, M.T., DuRant, R.H., Mitra, A., \& Rhodes, S.D. (2009). The role of monthly spending money in college student drinking behaviors and their consequences. Journal of American College Health. 57 (6), 587-595.

16. McGuire, B.L., \& Nunn, L.E. (2006). Maintain order and lose your shirt: Personal liability of educators in the classroom. Journal of College Teaching \& Learning, 3(10), 01-06.

17. O'Malley, P.M., \& Johnston, L.D. (2002). Epidemiology of alcohol and other drug use among American college students. Journal of Studies on Alcohol and Drugs, (Supplement 14), 23-39.

18. Pedersen, E., \& LaBrie, J. (2007). Partying before the party: examining prepartying behavior among college students. Journal of American College Health. 56 (3), 237-245.

19. Perkins, H.W., Meilman, P.W., Leichliter, J.S., Cashin, J.R., \& Presley, C.A. (1999). Misperceptions of the norms for the frequency of alcohol and other drug use on college campuses. Journal of American College Health, 47, 253-258. 
20. Perkins, H.W. (2003). The social norms approach to preventing school and college age substance abuse: a handbook for educators, counselors, and clinicians. San Francisco, CA: Jossey-Bass.

21. Presley, C.A., Meilman, P.W., \& Cashin, J.R. (1996). Alcohol and drugs on American college campuses: Use, consequences, and perception of the campus environment, Vol. IV, 1992-94. Carbondale, Ill.: Core Institute, Southern Illinois University.

22. Sanders, M. (2009). Counselors standing-by at SLU: 3 dead, 2 injured in Hammond hit-and-run. Retrieved from http://www.beloblog.com/WWLTV_Blogs/northshorenews/2009/03/counselors-standingby-at-slu3.html

23. Southeastern profile (2008). Retrieved from http://www.selu.edu/admin/ir/profile/2008/profile__2008.pdf

24. Wechsler, H., Lee, J.E., Kuo, M., \& Lee H. (2000). College binge drinking in the 1990s: a continuing problem: results of the Harvard School of Public Health 1999 college alcohol study." Journal of American College Health 48: 199-210.

25. Wills, E. (2005). 5-Campus Shuttle Makes Baltimore a 'College Town'. Chronicle of Higher Education. Retrieved from http://search.ebscohost.com.ezproxy.selu.edu

26. Zimmerman, R., \& DeJong, (2003). W. Safe Lanes on Campus: A Guide for Preventing Impaired Driving and Underage Drinking. Washington, D.C.: U.S. Department of Education, Higher Education Center for Alcohol, and Other Drug Prevention. 